\title{
A Spatio-temporal Study on Vulnerability of Women to Domestic Atrocities in the Social Environment of Kolkata City
}

\author{
Anuradha Mukherjee ${ }^{1}$ and Ranjan Basu ${ }^{2}$ \\ UGC-Senior Research Fellow ${ }^{1}$ and Professor ${ }^{2}$, Department of Geography, University of Calcutta, Kolkata
}

\begin{abstract}
Violence against women is a topical concern of the primate city of Kolkata in the State of West Bengal in India. There has been notable spurt in the incidences of crimes against women between 2001 and 2011 with a decadal growth rate of 8.18 per cent, while an annual growth rate of 80.32 per cent has been recorded from 2011 to 2012 in Kolkata city according to the reports of National Crimes Records Bureau (NCRB). Such victimizations take place regardless of age, socio-economic status as well as domestic and outside domestic frontiers. Thus, intra-city assessment of vulnerability to criminal victimization is necessary from the perspectives of social environ as well as demographic and socio-economic status of women in Kolkata. The present academic endeavour encompasses analyses of victimization of women in two heinous crimes which mainly take place within the so called 'secured domestic territory' of women viz. domestic violence and dowry deaths in eight Police Divisions under the jurisdiction of Kolkata Police from 2001 to 2015. The study has been undertaken to show spatial occurrences of such atrocities in Kolkata over time; the major areas of concentration of such crimes have been delineated along with their depiction through cartographic representation; and finally demographic and social status of the victims have been assessed to find out their risks of criminal victimization. The present work is therefore conducive of understanding how social and demographic conditions serve as impetus for women to become victims of various atrocities in the urban milieu of Kolkata.
\end{abstract}

Keywords: - vulnerability, social environ, domestic violence, dowry deaths, demographic and social status

\section{INTRODUCTION}

Indian urban societies are presumed to be educated as well as developed and therefore having an equitable gender condition unlike their rural counterparts. However, Indian mega-cities fail to prove the same as evident from the growing incidences of age old brutal practices like domestic violence and deaths of the brides due to dowry demands. Kolkata the primate city in the State of West Bengal is no exception to this trend, despite its acclaimed educational and progressive culture. The decadal growth rate of domestic violence in Kolkata between 2001 and 2011 had been 3.87 per cent which rapidly escalated to 31.68 per cent from 2011 to 2015. So far as dowry deaths are concerned, the number of such incidents remained the same for both 2001 and 2011 with annual fluctuations in the years in between and hence the decadal growth rate was nil. But between 2011 and 2015, there was a spurt in such deaths of young brides with the growth rate being 27.79 per cent in the city. Women in the city of Kolkata, like any other Indian cities, are considered to be most safe and secured within the domestic territory. However, such atrocities against them, mostly committed by their husbands and in-laws who are supposedly to protect them turn out to be the main offenders. Thus, neither the familial domain nor the realms outside it are secured for the women even in so called developed and progressive urban milieu of Kolkata. The present work has thus been undertaken to have a glimpse into the social space of women where they are most vulnerable to criminal victimization and find out the socio-demographic factors contributing to such victimization.

\section{LITERATURE REVIEW AND OBJECTIVES}

There have been several works done previously on victimization of women to domestic atrocities some of which relevant to this work have been critically apprised. Heise (1998) in his academic endeavour Population Reports: Ending Violence Against Women had devised a social ecology model in the context of partner abuse at four tiers-society, community, relationship and individual levels. It is definitely an intriguing work but the factors contributing to partner abuse at each of these levels vary between social communities and rural-urban milieu. Martin, et.al (1999) in their paper Domestic Violence in Northern India have systematically analysed various family association of domestic violence in the Indian context. They have extensively worked in Aligarh, Bandha, Gonada, Kanpur Nagar and Nainital districts of Uttar Pradesh. They have also elaborated types of domestic violence faced by women. However, the work had lesser emphasis on the rural-urban variation of such a crime in the study area. Harihar Sahoo and Manas Ranjan Pradhan (2000), in their work Domestic 
Violence in India: An Empirical Analysis have mentioned two determinants of domestic violence are- i) standard of living index and ii) women's autonomy within the household. They have quite extensively worked on the incidences of domestic violence and in different States of India relating the socio-demographic factors like age groups, age of marriage, community etc., but no significant causes of such spatial variation was explained which was necessary to substantiate their academic proposition. A research study by the Yugantar Education Society in Nagpur (2005) in their work A Study on Nature, Extent, Incidence and Impact of Domestic Violence Against Women in the States of Andhra Pradesh, Chhattisgarh, Gujarat, Madhya Pradesh and Maharashtra have vividly dealt with the issue considering several parameters like age groups, educational level, health along with marital status, economic background and host of impacts of such violence such as emotional, economic and physical abuse. It is indeed a path-breaking work which considers both rural and urban counterparts and greatly influences the present work. The World Health Organization (2005) in their Summary Report on WHO Multi-country Study on Women's Health and Domestic Violence against Women elaborately discussed on partner abuse, non-partner abuse, impact of such abuse on women's health and the way women cope with such circumstances in the countries of Japan, New Zealand, Thailand, Bangladesh, Ethiopia, Tanzania, Namibia, Serbia, Montenegro, Brazil, Peru and Samoa Island. It is interesting to learn the status of women in other parts of the world in association with their societal set up. But the work could have been made more balanced if such study was conducted in any of the first world European or North American countries.

\section{Objectives}

- To find out the intra city spatial variation of the incidences of domestic violence and dowry deaths in Kolkata

- To study the temporal changes of the incidences of domestic violence and dowry deaths within the city

- To assess the vulnerable factors that are responsible for victimization of women to such atrocities

- To specify the probable causes for such victimization

\section{MATERIALS AND METHODS}

The work is based on secondary data source obtained from the records and briefs of Kolkata Police which have been collected for the period of fifteen years ranging between 2001 and 2015. The data have been tabulated and relevant quantitative methods have been applied to analyse the spatio-temporal variations of domestic violence and dowry deaths in different neighbourhoods of the city. The secondary data have been collected for eight Divisions under the jurisdiction of Kolkata Police, viz. - North Division (ND), Central Division (CD), Eastern Suburban Division (ESD), South Division (SD), Port Division (PD), South East Division (SED), South West Division (SWD) and South Suburban Division (SSD). However, till the latter half of 2011, there had been only five Divisions under Kolkata Police which were North Division (ND), Central Division (CD), Eastern Suburban Division (ESD), South Division (SD) and Port Division (PD). The Kolkata Police jurisdiction area expanded after the State Assembly election in 2011, as some parts of South 24 Parganas District Police (which fall under Municipal Corporation area of Kolkata but were not included under the Police jurisdiction area) were added to it.

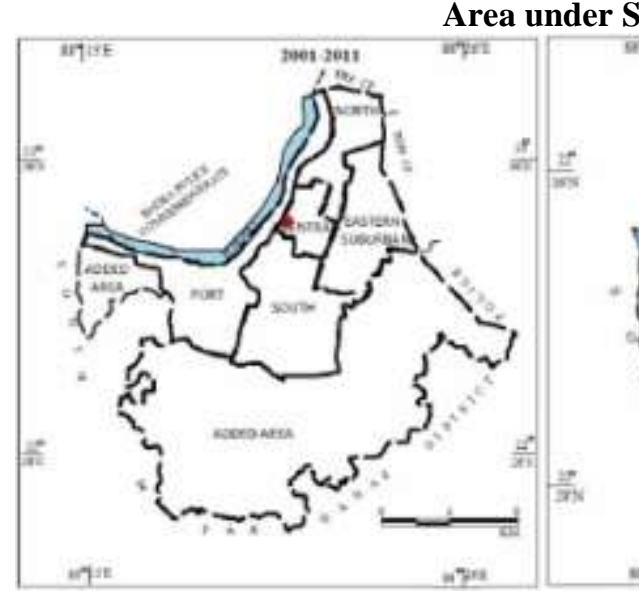

Fig. 1(a)

Map source: Kolkata Police

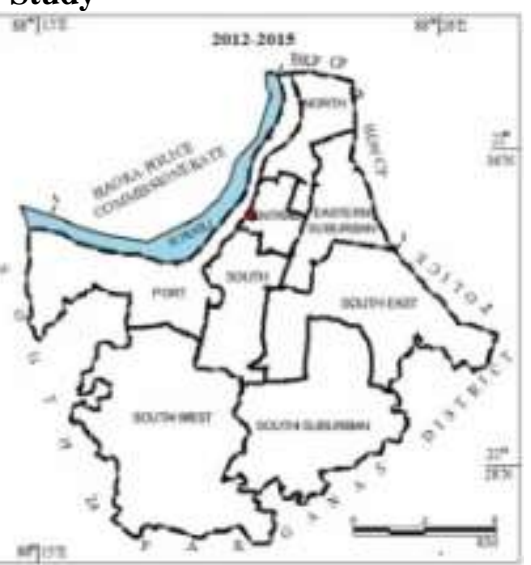

Fig. 1(b)

The spatio-temporal analyses have been represented through cartographic depictions and interpretations have been made accordingly. Apart from the formal reported records of sensitive issues like domestic violence and dowry deaths, there are several such incidences which go totally unreported. Studying a number of literature as well as from the discussion with the target group (the potential victims of domestic 
violence), there came up several reasons for which such illegal atrocious activities had gone unreported. The reasons for non-reporting of these crimes have been discussed in this work.

IV. RESULTS

The spatio-temporal analyses reveal the following results which have been discussed under the following heads:

Social Ecology of Domestic Abuse and Vulnerable Factors: Heise in 1998 proposed a social ecology model regarding partner abuse, which has been depicted in figure 2 . The model pragmatically explains the factors of vulnerability to victimization of domestic outrages and partner abuse at four tiers of the society - society, community, family and individual level. The model considers the vulnerable factors both from the perspectives of the offender as well as that of the victims. At societal level gender notions and gender norms seem to be the factors responsible for outrages against women, while poverty and delinquent peer association result in such offences at community level. Again, at family level or relationship level gender specific role of the decision maker in the family determines the status of women and behaviour towards them, whereas at individual level one's moral conscience and value system along with childhood experience of violence are the key factors which make an offender or a victim vulnerable to crime.

\section{Social Ecology Model of Partner Abuse (after Heise, 1998)}

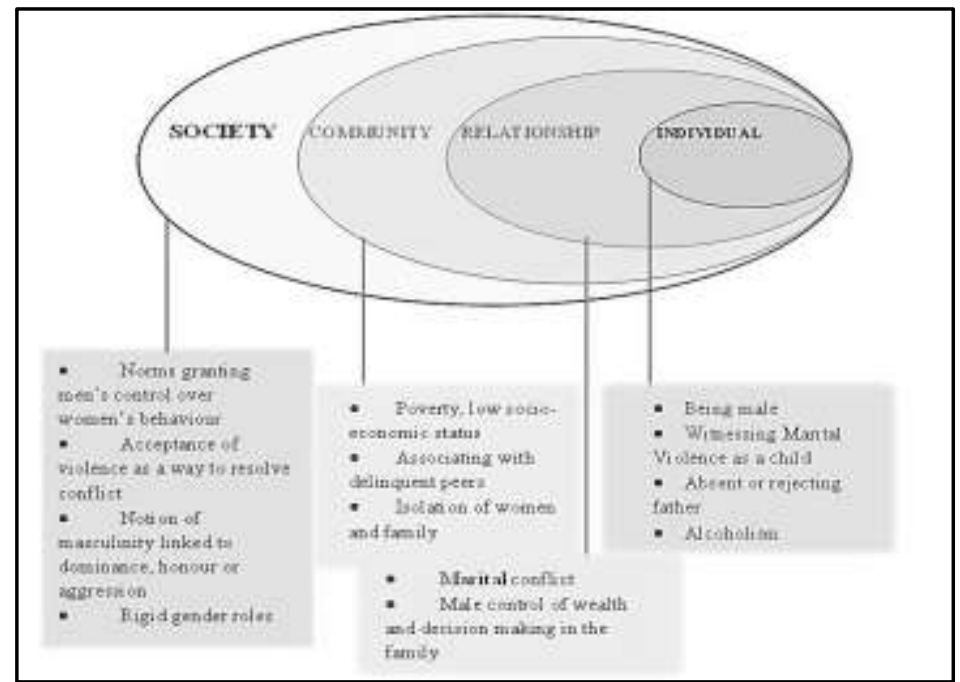

Fig.2

Source: Unique Crime: Understanding Rape in India,Ed. Swati Bhattacharjee, 2008

Thus it is clear that, so far as domestic violence and partner abuses are concerned, not only individuals and the family but also community and society at large have their respective roles to play in such cases of victimization of women.

Spatio-temporal dimensions of Domestic Violence: Domestic violence has been articulated under Section 498 A of the Indian Penal Code (IPC). According to this Section cruelty to a woman implies any wilful conduct which is likely to drive the woman to commit suicide or to cause grave injury or danger to life, limb or health (whether mental or physical) of the woman by husband or the relative of husband; or harassment of the woman where such harassment is with a view to coercing her or any person related to her meet any unlawful demand for any property or valuable security or is on account of failure by her or any person related to her to meet such demand (Gaur, 2014). A significant intra-city variation of the incidences of domestic violence has been observed as evident from the figures 3(a), (b) and (c) which show the average ranks of the incidences of domestic violence over a period of 15 years at five years interval. The Central Division (CD), which comprises of the central business district and commercial hub of the city has a consistent low rank in the incidences of domestic violence. Being commercial in character, there is lesser number of family residences compared to corporate houses in this Police Division and therefore family feuds are lesser in number. Thus, the chances or risks of occurrences of domestic violence are much less. This can be well corroborated with the adjacent diagrams which reveal lower ranks of domestic violence in Central Division owing to lower number of such incidents. 
Temporal Changes in Police Division-wise Ranks of the Incidences of Domestic Violence inKolkata City, 2001-2015
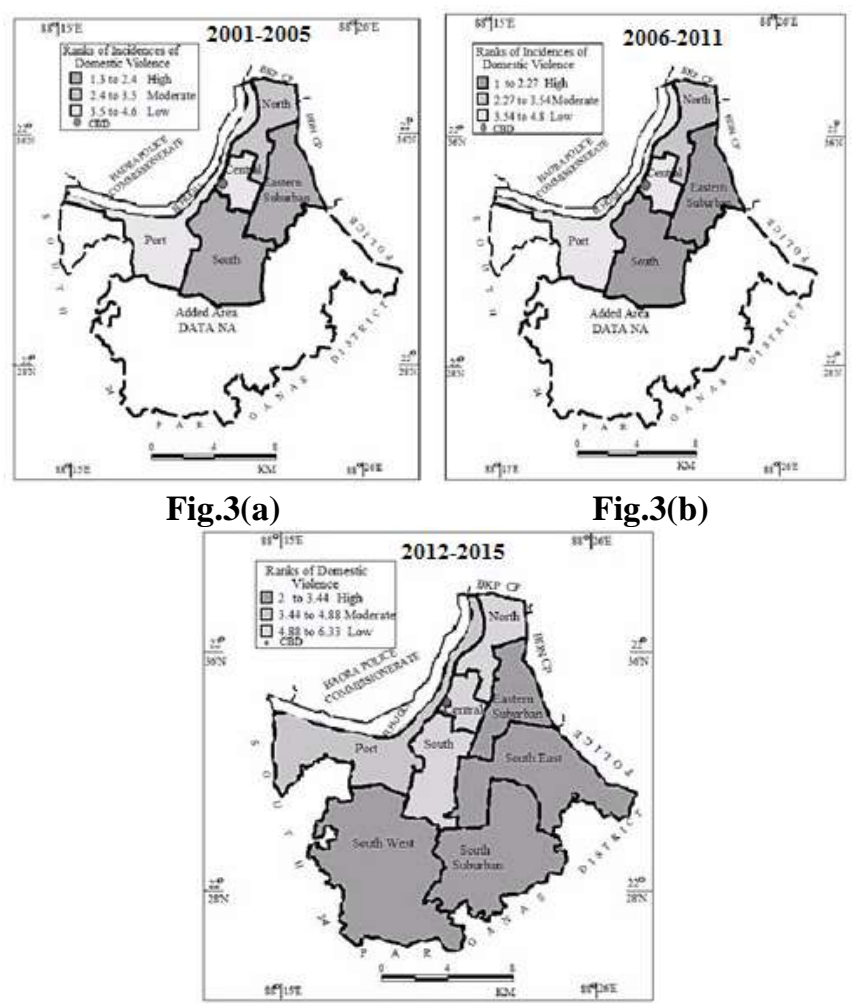

Fig.3(c)

Data source: Computed by the authors from data provided by Kolkata Police

The Police Divisions around the fringe area of the city like the Eastern Suburban Division (ESD) and South Division (SD) in 2001-2005 and 2006-2011, Eastern Suburban Division (ESD), South East Division (SED), South Suburban Division (SSD) and South West Division (SWD) in 2012-2015 show higher ranks in incidences of domestic violence. It is noteworthy to mention in this context that, the degree of slum (proportion of slum households to total households) is higher in the eastern and south-eastern fringe of the city. Unfortunately, slum areas of the highly urbanized core of Kolkata are still backward in terms of socio-economic condition which affects their value system adversely. Women are not economically empowered. Family feuds are common along with rampant demands for dowry. These are some of the factors responsible for torture on women as they neither have social stance nor economic footing for protecting themselves. The victims most often are silent about their torture because of lesser educational qualification and lack of economic empowerment which culminate into a state of low self-esteem in their attitude and behaviour. They feel that protest would result in even more troubles in their lives. These factors generally account for the causes of higher ranks in the instances of domestic violence in the fringe area and slums of the city.

Table 1: Growth Rate of Domestic Violence under Various Police Divisions in Kolkata City

\begin{tabular}{|l|r|r|}
\hline \multirow{2}{*}{ Police Divisions } & \multicolumn{2}{|c|}{ Growth Rate (in percentage) } \\
\cline { 2 - 3 } & 2001-2011 & 2011-2015 \\
\hline North & 4.62 & 9.10 \\
\hline Central & 4.89 & -0.81 \\
\hline Eastern Suburban & 4.74 & -2.60 \\
\hline South & 0.60 & -1.47 \\
\hline Port & 6.72 & 13.06 \\
\hline South East & - & 0.99 \\
\hline South West & - & 2.69 \\
\hline South Suburban & - & 5.26 \\
\hline
\end{tabular}

Data source: Computed by the authors from data provided by Kolkata Police 
Table 1 provides an account of growth rate of incidences of domestic violence in different spans of times under the various Police Divisions of Kolkata. Almost all the Police Divisions reveal decadal as well as quinquennial increase from 2001 to 2011 and 2011 to 2015 respectively, except Central, Eastern Suburban and South Divisions which record negative quinquennial growth. However, Eastern Suburban Division records incidences of domestic violence more in number than other Police Divisions in the city.

Spatio-temporal dimensions of Dowry Deaths: Section 304 B of the Indian Penal Code defines dowry death as - death of a woman caused by any burn or bodily injury or occurs otherwise than under normal circumstances within seven years of her marriage and it is shown that soon before her death she was subjected to cruelty or harassment by her husband or any relative of her husband for or in connection with any demand for dowry (Gaur, 2014). The scenario of dowry deaths is also somewhat similar to that of the domestic violence in various Police Divisions of Kolkata city as evident from figures 4(a), (b) and (c). As for this type of crime the women living in the backward areas of the city are more victimized. In case of dowry deaths there has been a spatial shift of the areas recording higher incidences of dowry deaths, from the western part of the city in the Port Division (PD) to the eastern and south suburban areas between 2001-2005 and 2006-2011 as well as during the period of 2012-2015. The western part of the city is socio-economically backward and is mostly dominated by the minority religious communities. The Eastern Suburban (ESD), South Eastern (SED) and South Suburban Divisions (SSD) in the eastern and south eastern fringe of the city have higher number of slum households and hence are marked by abject poverty. Thus all these areas, whether in the western part of the city or eastern and south suburban fringes, which record higher incidences of dowry deaths fall under either of the two socioeconomically characterized spatial sets of backward areas. Historically, the evil of dowry was associated with upper caste Hindus. But over time people of other religions like Islam and Christianity (which prohibit such a custom) have tried to emulate this malpractice of the Hindus (Shaban, 2010). This explains the situation of higher incidences in the extreme western and south suburban parts of the city. People living in these areas out of their poverty, seek economic gains from marital alliances and non-fulfilment of such demands make them hostile towards the brides. Such intolerance, create in them momentary rages beyond the self-control of their morality or value system and often end up in bride burning or deaths of young brides by various other atrocious acts. Although, there had not been any significant growth rate in the incidences of dowry death between 2001 and 2011, but between 2012 and 2015 it spurted up to 27.19 per cent while between 2001 and 2015 it was as high as 92.93 per cent.

Temporal Changes in Police Division-wise Ranks of the Incidences of Dowry Deaths in Kolkata City, 2001-2015

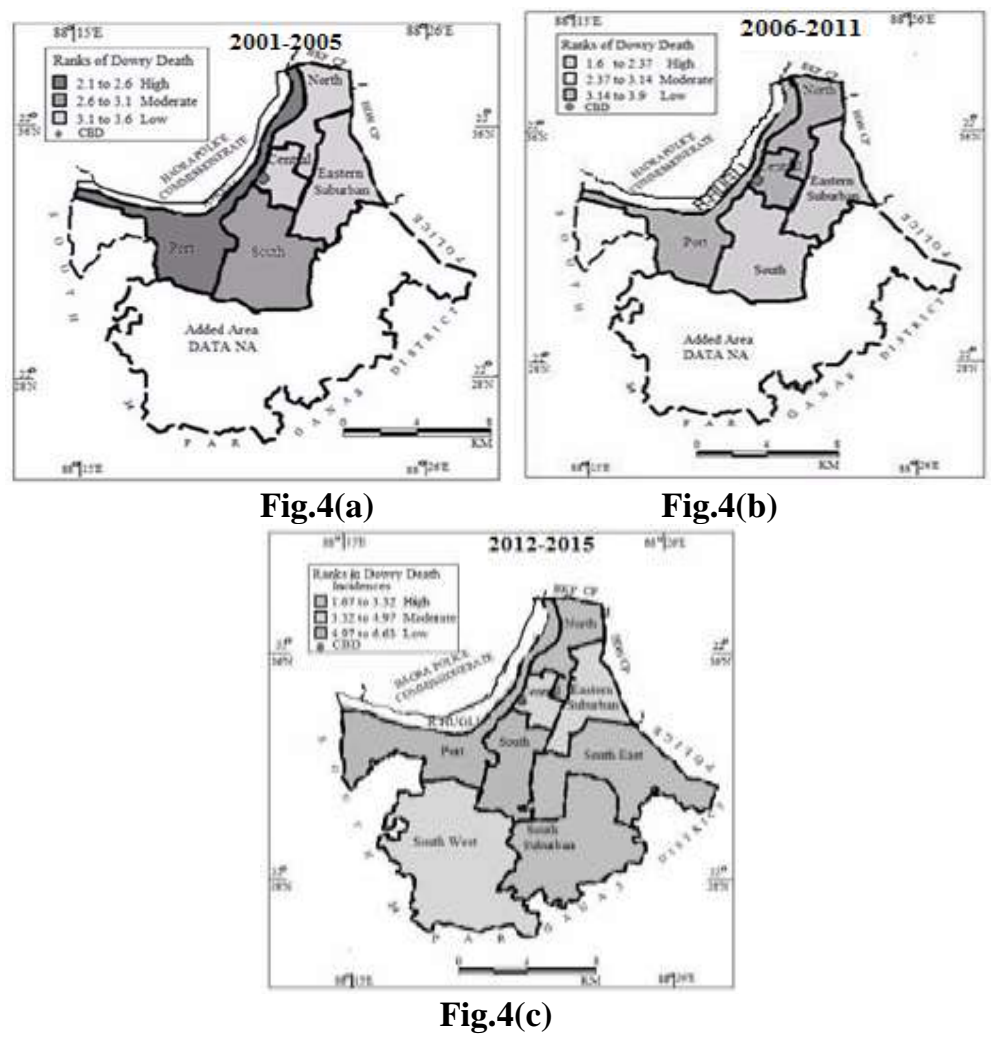

Data source: Computed by authors from data provided by Kolkata Police 
Table 2 reveals temporal changes in the incidences of dowry deaths in the Police Divisions Kolkata. The general trend as has been observed in case of dowry deaths is that, such incidences in most of the Police Divisions have remained unchanged over the decade between 2001 and 2011 as well as that between 2011 and 2015. South Suburban Division has recorded negative growth, but the number of incidences in this Division has remained high compared to other Police Divisions as evident from the spatial ranks in Fig. 4. Other Police Divisions have, however, recorded fairly high positive growth rate.

Table 2: Growth Rate of Dowry Deathsunder Various Police Divisions in Kolkata City

\begin{tabular}{|l|r|r|}
\hline \multirow{2}{*}{ Police Divisions } & \multicolumn{2}{|c|}{ Growth (in percentage) } \\
\cline { 2 - 3 } & 2001-2011 & $\mathbf{2 0 1 1 - 2 0 1 5}$ \\
\hline North & 11.61 & 0 \\
\hline Central & 7.17 & 0 \\
\hline Eastern Suburban & 0 & 10.66 \\
\hline South & 0 & 0 \\
\hline Port & 0 & 0 \\
\hline South East & - & 7.45 \\
\hline South West & - & 3.31 \\
\hline South Suburban & - & -9.61 \\
\hline
\end{tabular}

Data source: Computed by the authors from data provided by Kolkata Police

\section{DISCUSSION}

A spatio-temporal trend of domestic atrocities against women of Kolkata involve discussion on several vulnerable factors under the following heads-

Factors Vulnerability to Victimization of Domestic Atrocities: Studying the records of the Kolkata Police regarding domestic violence and dowry deaths, some socio-demographic factors have been ascertained which make the potential victims vulnerable to such domestic atrocities. These factors are-

- Age of the Victim: It has been observed that women belonging to young age group are getting victimized more in number. For instance both the Tables 3 and 4 reveal the age group-wise victimization of women to domestic violence and dowry death.

Table 3: Age Group-wise Victimization of Domestic Violence in Kolkata, 2001-2015

\begin{tabular}{|l|r|}
\hline $\begin{array}{c}\text { Age Groups } \\
\text { (in Years) }\end{array}$ & $\begin{array}{c}\text { Percentage of Victims of } \\
\text { Domestic Violence }\end{array}$ \\
\hline 18 to 20 & 35.06 \\
\hline 21 to 23 & 6.82 \\
\hline 24 to 26 & 43.20 \\
\hline 27 to 30 & 10.92 \\
\hline Above 30 & 4.00 \\
\hline
\end{tabular}

Table 4: Age Group-wise Victimization of Dowry Deaths in Kolkata, 2001-2015

\begin{tabular}{|l|r|}
\hline $\begin{array}{c}\text { Age Groups } \\
\text { (in Years) }\end{array}$ & $\begin{array}{c}\text { Percentage of Victims of } \\
\text { Dowry Death }\end{array}$ \\
\hline 18 to 20 & 41.98 \\
\hline 21 to 23 & 25.19 \\
\hline 24 to 26 & 16.79 \\
\hline 27 to 30 & 16.03 \\
\hline
\end{tabular}

Data source: Compiled by the authors from data provided by Kolkata Police

It is evident from the Tables 3 and 4, that about 43.20 per cent of brides of younger age group between 24 and 26 years are mostly victimized for domestic violence, while about 41.98 per cent of the brides belonging to the age group of 18 to 20 years are victimized of demands for dowry. Being quite young at age the victims are fragile enough to stand for themselves. Moreover, at such ages they are not mature enough to be economically and socially empowered to protest their victimization. Most of them are economically dependent either on their husbands and in-laws or their paternal family. Therefore, their perpetrators, being husbands and in-laws, take advantage of their age and economic weakness to victimize them. 
- Power Structure in the family: In case of domestic outrages within the household domain, power structure in the family is a vulnerable factor for victimization of women. According to Sushma Kapoor, violence against women in domestic sphere is mainly perpetrated by men who have been bestowed with decision making power in the family and they include husbands, fathers-in-law, brothers-in-law etc. (Kapoor, 2000). However, according to the Police in Kolkata, it has been found that there is a marked deviation from Kapoor's observations. Although, husbands play the role of decision maker in most of the households and are also responsible for domestic violence, but mothers-in-law and sisters-in-law are main committers of domestic violence. In most cases they are not the economic decision makers in the family, yet, when it comes to domestic feuds, they remain at the forefront. Thus power equation in the family, whether it vested with the male head or female head of the family is important to the vulnerability of women to such offences.

- Alcoholism: Addiction of the husband is yet another factor which makes the potential victim vulnerable to domestic violence. Under such obnoxious intoxication, men often lose their control over their morality and become brutal towards their spouses.

Major Causes of Domestic Atrocities: Some of the major causes of domestic atrocities as have been gathered from the Police records is listed as follows:

- Non-fulfilment of dowry demands by the family of the in-laws

- Family feud

- Property disputes

- Extra-marital relation of the either of the spouse

Major Causes of Non-reporting of Domestic Atrocities: Although there has been much hue and cry about the torture of women within the domestic arena, yet large shares of such atrocities go unreported and unheard by the law keepers of the society. There are several causes of non-reporting of the incidences of domestic violence which may be listed as follows:

- Economic insecurity plays a major role in non-reporting of domestic violence if the woman is financially dependent on her husband and in-laws for her own personal expenses

- Inability to take the cudgel of wards single handed due to economic dependency on husband and in-laws

- Women do not lodge complaint of domestic violence in order to preserve honour of the family

- Many-a-times family forces a woman not to go to the police for lodging complaint against domestic violence

- Sometimes, emotional reasons like blind fondness for spouse or in-laws prevent women from lodging complaint despite they face such atrocities

Major Findings of the Study: The major findings of the study may be summarized as follows:

- The spatial ranking of the incidences of domestic violence and dowry deaths are found to be higher in the fringe areas of the city, more so in the newly added area from South 24 Parganas in 2011. These areas still belong to urban shadow zone and also comprise of slums characterized by socio-economically blighted areas which account for such crimes as has been discussed earlier.

- Police Divisions recording lower decadal (2001-2011) or quinquennial (2011-2015) growth rate of such crimes represent higher spatial rank of domestic violence and dowry deaths, while those recording higher growth rate, represent lower spatial rank over these periods of time.

- Women belonging to a younger age group between 18 to 20 years and 21 to 23 years are highly victimized for dowry deaths and domestic violence in Kolkata between 2001 and 2015. There are several socio-demographic factors contributing to such victimization which have already been discussed earlier.

- The major causes of domestic atrocities mainly concentrate around dowry demand. Family feud and property related disputes are some of the other factors which cause domestic atrocities.

- Despite, women face several atrocities in the domestic front, yet, a large percentage share of such brutalities go unreported for various reasons as have been specified earlier.

Suggested Remedial Measures to Combat Domestic Atrocities: Nothing is more appropriate than change in the attitude of the society towards women in combating domestic wraths committed on them. Even sometimes women make themselves vulnerable to such outrages. In order to address the issue of domestic violence properly, there may be two strategic stand pints that can be adopted in the society. Firstly, there should be effective implementation of the legal protection measures which need to be adopted. These include - stringent legal prohibition on early marriages and school dropouts of the girls for marriage along with strict socio-legal embargo on exchange of wedding gift in disguise of dowry. Appropriate and effective enforcement of penal 
codes against the perpetrators must be executed so that examples are set and the fear of punishment work on the offenders so that they restrict themselves to commit crimes. These should be adopted at large scales not only in rural areas but also in urban cores like Kolkata to prevent such violence against women. The second strategy comprises of social reaction measures. Complaints against domestic violence must be lodged to the police. Often the perpetrators get scot free as no complaints are made against them due to several reasons as have been discussed earlier and thus they feel they have every right to recur torture on women. The commitments of the Community Police wing of Kolkata Police are worth mentioning in this context. They work with a motto of well-being and community development for the disadvantaged sections of the society like the senior citizens, the potential truant street children etc. through unconventional ways of policing. This section of Kolkata Police must have provision for the protection of married women from domestic violence as well. The number of Women Police Stations is adequate in Kolkata but their effective functioning in making women of the city secured needs to be monitored regularly. Women have to be made aware on their legal and human rights so that they can stand affirm on their self- esteem to prevent violence against them.

\section{CONCLUSION}

In an era where much importance is given to gender development and many of the human development measures are women centric, it is unfortunate to note that women still continue to fall prey to social atrocities of various kinds, even by their near and dear ones. Realization of gender development is retarded with the incidences of atrocities against women. It has been observed that that even gender empowerment with its existing parameters fail to actually empower women. None of the existing gender development parameters ensure their safety and provide them with freedom from fear of crime. It is evident that the prevailing legal measures protecting women's rights are not adequate to ensure their safety. Apart from such legal measures mass moral awareness regarding equality in honour and status of women at all levels may be alternatives for a better future of women in the country. Other development parameters like basic education, equal right and access to economic resources and assets, economic empowerment are necessary to be ensured to every woman. At the same time, every woman irrespective of their socio-economic status must strive for financial independence and empowerment in order to realize their self-worth and protect their own self-esteem.

\section{In Print Media}

\section{SELECTED REFERENCES}

[1] Gaur, K.D. (2014): 'Textbook on Indian Penal Code ', Universal Law Publishing Co. Pvt. Ltd., New Delhi

[2] Heise L. (1998): 'Violence against Women: An Integrated, Ecological Framework', Violence Against Women 4(3),Sage Kolkata Police Records (2001-2015), Government of West Bengal, Kolkata

[3] Shaban, A.(2010): 'Mumbai: A Political Economy of Crime and Space', Orient Black Swan, New Delhi

\section{In Electronic Media}

[4] Kapoor, S. (2000): 'Domestic Violence against Women and Girls', Innocenti Digest 6,Innocenti Research Centre, Florence, Italy

http://www.unicef-irc.org/publication/pdf/digest6e.pdf(accessed on 25.12.2016)

[5] Martin, S.L., Tsul, A.O, Maitra, K. and Marinshaw R.(1999): Domestic Violence in Northern India, American Journal of Epidemology, USA

http://www.aje.oxfordjournals.org/content/15/4/417.full.pdf(accessed on 25.12.2016)

[6] National Crime Records Bureau (2001-2015): 'Crime in India', Ministry of Home Affairs, Government of India, New Delhi

http://www.ncrb.nic.in(accessed on 20.12.2016)

[7] Sahoo H. and Pradhan M.R. (2000): 'Domestic Violence in India: An Empirical Analysis'

https://www.researchgate.net/publication/230859625 (accessed on 04.01.2017)

[8] World Health Organization (2005): WHO Multi-country Study on Women's Health, Switzeland www.who.int/gender/violence/who(accessed on 04.1.2017)

[9] Yugantar Education Society in Nagpur (2005) : 'A Study on Nature, Extent, Incidence and Impact of Domestic Violence Against Women in the States of Andhra Pradesh, Chhattisgarh, Gujarat, Madhya Pradesh and Maharashtra'

http://planningcommission.nic.in/reports/sereport/ser/stdy_demvio.pdf (accessed on 04.1.2017) 